\title{
Kelompok Usaha Kerupuk Beras di Desa Jombang Kecamatan Jombang Kabupaten Jember
}

\author{
Deni Esti Lestari \\ STIE Widya Gama Lumajang \\ deniestilestari@gmail.com
}

\begin{abstract}
ABSTRAK
Kerupuk merupakan jenis makanan ringan yang dapat diperoleh dimana saja tempatnya baik di pedesaan maupun perkotaan. Selain sebagai bahan pelengkap makan tidak sedikit masyarakat yang menggunakan sebagai camilan atau makanan ringan untuk bersantai. Semakin banyak peminat kerupuk mempengaruhi banyak home industri kerupuk yang berkembang pesat. Salah satunya adalah Home Industry Krupuk Bu Endah. Hal ini menyebabkan pola pikir masyarakat berkembang. Menjadikan masyarakat lebih inovatif dan kreatif untuk berwirausaha dalam bidang pangan khususnya krupuk. Dengan alasan di atas penulis memilih mitra pengabdian $\mathrm{Bu}$ Endah untuk mengetahui lebih lanjut tentang proses produksi kerupuk.
\end{abstract}

Kata Kunci: Kerupuk Beras, Kelompok Usaha

\begin{abstract}
Crackers are a type of snack that can be obtained anywhere in rural or urban areas. Aside from being a food supplement, not a few people use it as a snack or snack to relax. More and more crackers enthusiasts affect many cracker home industries that are growing rapidly. One of them is the Bu Endah Krupuk Home Industry. This causes the mindset of developing people. Making the community more innovative and creative for entrepreneurship in the field of food, especially crackers. With the above reasons the writer chose Bu Endah's devotion to find out more about the cracker production process.
\end{abstract}

\section{Keywords: Rice Crackers, Business Group}

\section{PENDAHULUAN}

\section{A. ANALISIS SITUASI}

Krupuk beras merupakan salah satu krupuk yang banyak digemari oleh masyarakat mulai dari kalangan anak-anak hingga kalangan dewasa. Krupuk beras ini memiliki tekstur yang sangat renyah dan memiliki rasa yang gurih. Pamor dari krupuk beras ini rupamya sudah banyak dikenal oleh masyarakat sejak jaman dahulu dan hingga saat krupuk beras menjadi krupuk yang banyak dicari oleh masyarakat untuk dijadikan lauk saat mereka makan. Jika dilihat dari jumlah penggemar olahan krupuk beras ini memang tidak pernah ada sepinya. 
Home industry merupakan rumah usaha atau perusahaan kecil yang menghasilkan barang, kegiatan ekonominya dipusatkan di rumah. Home industry biasanya didirikan oleh seseorang dengan modal yang tidak terlalu besar dan area pemasarannya juga belum luas. Dizaman yang modern ini ada banyak sekali usaha rumahan yang ada disekitarkita, bahkan lokasi pemasarannya sudah meluas. Seseorang yang mempunyai usaha rumahan mempunyai suatu keterampilan dalam usaha, home industri mempunyai sedikit karyawan kurang dari 4 orang yang biasanya oleh anggota keluarga sendiri maupun tetangga terdekat.

Kerupuk merupakan makanan ringan namun sangat berarti sebagai pelengkap makan, kerupuk sangat memasyarakat di lidah penduduk Indonesia dari kalangan menengah ke bawah sampai menengah ke atas. Banyak orang yang mengkonsumsi kerupuk untuk teman makan dan banyak sekali orang yang tidak bisa menikmati enaknya makan karena tidak ditemani kerupuk. Kerupuk merupakan jenis makanan ringan yang dapat diperoleh dimana saja tempatnya baik di pedesaan maupun perkotaan. Selain sebagai bahan pelengkap makan tidak sedikit masyarakat yang menggunakan sebagai camilan atau makanan ringan untuk bersantai. Semakin banyak peminat kerupuk mempengaruhi banyak home industri kerupuk yang berkembang pesat. Salah satunya adalah Home Industry Krupuk Bu Endah. Hal ini menyebabkan pola pikir masyarakat berkembang. Menjadikan masyarakat lebih inovatif dan kreatif untuk berwirausaha dalam bidang pangan khususnya krupuk. Dengan alasan di atas penulis mengadakan Observasi Home Industry Krupuk Bu Endah untuk mengetahui lebih lanjut tentang bagaimana kerupuk dapat diproduksi.

\section{B. PERMASALAHAN}

Berdasarkan studi pendahuluan dan analisis situasi yang telah dilakukan, kelompok mitra mempunyai permasalahan sebagai berikut :

1. Minimnya pengetahuan mitra tentang strategi pemasaran yang tepat untuk usaha.

2. Minimnya pengetahuan mitra tentang cara mengemas produk agar menarik konsumen.

3. Lemahnya penggunaan teknologi dan informasi sebagai media promosi.

\section{SOLUSI DAN TARGET LUARAN}

\section{A. SOLUSI}

Solusi yang ditawarkan dalam kegiatan pengabdian masyarakat pada mitra di kecamatan Jombang, sebagai berikut : 
1) Memperkuat pengetahuan mitra tentang strategi pemasaran, khususnya pada usaha kerupuk beras di kecamatan Jombang kabupaten Jember.

2) Meningkatkan pengetahuan mitra tentang cara mengemas produk yang menarik.

3) Meningkatkan penjulan dengan media promosi.

\section{B. TARGET KEGIATAN}

Kegiatan pengabdian ini diharapkan dapat menghasilkan target sesuai dengan harapan kelompok mitra, sebagai berikut:

1) Peningkatan kemampuan mitra dalam menjalankan usahanya dengan bekal strategi pemasaran yang tepat.

2) Mitra mampu mempromosikan dan berkomunikasi melalui media personal maupun non personal.

3) Mitra tidak hanya mampu mengolah produk, tetapi dapat meningkatkan penjualan melalui media promosi.

\section{METODE PELAKSANAAN}

\section{A. Tahapan dalam Melaksanakan Solusi}

Dari permasalahan diatas maka ada beberapa solusi yang ditawarkan melalui tahapan tahapan sebagai berikut :

1. Tahapan pertama : pelaksanaan survey kepada mitra guna melihat kondisi usaha mitra.

2. Tahapan kedua : pelaksanaan wawancara kepada mitra guna menggali berbagai permasalahan-permasalahan usaha dan menggali berbagai informasi terkait dengan usaha.

3. Tahapan ketiga: mendesign spanduk untuk promosi

4. Tahapan keempat : pendampingan pemasaran dengan kelompok usaha kerupuk beras di daerah terdekat, pendampingan promosi online.

5. Tahapan kelima : monitoring dan evaluasi.

\section{B. Metode Pendekatan yang Ditawarkan}

Metode pendekatan yang ditawarkan untuk menyelesaikan permasalahan mitra terdiri dari langkah-langkah sebagai berikut :

1. Survey

Kegiatan survey akan dilaksanakan guna melihat kondisi usaha mitra. 
2. Wawancara

Pelaksanaan wawancara bertujuan untuk menggali informasi terkait permasalahanpermasalahan mitra dan sekaligus menemukan solusinya

3. Praktek mendesign spanduk untuk promosi

Praktek membuat spanduk dibantu oleh dosen dengan mendesign spanduk yang lebih menarik dan unik.

4. Monitoring dan evaluasi

Kegiatan monitoring dan evaluasi akan dilaksanakan secara periodik sampai mitra dapat mempromosikan produk sehingga target dan luaran program ini bisa tercapai.

\section{HASIL YANG DI CAPAI}

\section{Kegiatan Survey}

Kegiatan survey dilakukan pada tanggal 14-15 April 2018, temuan survey diketahui bahwa usaha ini kurang berkembang pada aspek promosi. Kegiatan survey juga menghasilkan serangkaian susunan program pengabdian masyarakat yang selanjutnya dan tentunya dibahas oleh mitra dan pelaksana program pengabdian msyarakat. Berikut merupakan hasil dokumentasi kegiatan survey pada kelompok usaha obat pertanian di desa Jombang Kecamatan Jombang Kabupaten Jember.

\section{Kegiatan Wawancara}

Langkah kedua dalam pelaksanaan program pengabdian masyarakat adalah kegiatan wawancara. Wawancara diperlukan untuk menggali informasi terkait usaha pertanian, informasi yang digali berupa identitas usaha, modal dan omset, harga jual, dan strategi promosi yang diterapkan selama ini.

Kegiatan wawancara dilaksanakan pada tanggal 14 April 2018, hasil wawancara menunjukkan usaha kerupuk beras bu Endah memiliki permasalahan dalam bidang pemasaran dan promosi. Pemasaran usaha tidak berjalan lancar baik secara offline maupunonline. Pendampingan strategi promosi terhadap pelaku usaha ini sangat diperlukan agar pelaku usaha dapat meningkatkan penjualan.

\section{Identitas Usaha}

Pada tahun 2010 Bu Endah Sekeluarga mempunyai inisiatif untuk mendirikan sebuah home industri krupuk. Sebelum bu Endah mendirikan usaha tersebut beliau bekerja sebagai kuli di pabrik krupuk. Dengan pengalaman dan keahlian yang beliau miliki maka beliau 
bertekad untuk mendirikan tempat usaha. Dari mulut ke mulut lambat laun usaha industri krupuk ini di kenal masyarakat banyak sehingga berkembang dengan pesat hingga sekarang. Faktor utama yang mendorong Bu Endah membuka usaha krupuk ini karena beliau telah memperoleh ilmu dari pabrik krupuk tempat beliau bekarja, Bu Endah juga ingin memutar roda kehidupan menjadi lebih baik, selain itu Bu Endah ingin menciptakan lapangan kerja bagi warga sekitar.

\section{Iklan dan Spanduk}

Spanduk merupakan suatu media informasi, spanduk ialah kain membentang dan biasanya berada ditepi-tepi jalan yang berisi tulisan, warna dan gabar. Spanduk dapat kita buat sendiri bisa dengan menggunakan car, sablon "screen printing" ataupun dengan cara print digital. Secara umum spanduk dibagi dalam dua macam yakni spanduk kain dan spanduk MMT. Spanduk kain biasanya dikerjakan dengan cat, sablon ataupun dengan print digital. Sementara untuk spanduk berbahan MMT hanya bisa dikerjakan dengan print digital.

Spanduk berfungsi sebagai media promosi baik itu berupa produk/jasa, acara, sekolah dan sebagainya. Selain itu spanduk merupakan media promosi yang murah dan sangat efektif. Dengan melihat spnduk yang menarik, konsumen pun akan tertarik untuk membeli produk atau jasa kita. Setidaknya itu sudah terbukti dengan banyaknya spanduk yang terpasang di pinggir-pinggir jalan araya. Spanduk memang menjadi media promosi yang murah dan efektif untuk saat ini.

\section{Proses Produksi}

Menurut Assauri, produksi didefinisikan sebagai berikut : "Produksi adalah segala kegiatan dalam menciptakan dan menambah kegunaan (utility) sesuatu barang atau jasa, untuk kegiatan mana dibutuhkan faktor-faktor produksi dalam ilmu ekonomi berupa tanah, tenaga kerja, dan skill (organization, managerial, dan skills). Dalam kegiatan produksi, manajemen berfungsi sebagai planning/perencanaan, dimana perencanaan akan dibuat terlebih dahulu sebelum melakukan kegiatan proses produksi. Menurut Ahyari (2002) proses produksi adalah suatu cara, metode ataupun teknik menambah keguanaan suatu barang dan jasa dengan menggunakan faktor produksi yang ada.

Dalam proses produksi membutuhkan waktu yang berbeda-beda, ada yang sebentar, misalnya pembuatan kain, pembuatan televisi, dan lain-lain. Tetapi, ada juga proses produksi yang dapat dinikmati langsung hasilnya oleh konsumen, misalnya pentas hiburan, pijat, dan produksi lain-lainnya. 
Untuk bisa memproduksi krupuk beras ini juga harus didukung dengan SDM yang berkualitas yang diharapkan dapat membantu dalam proses operasional usaha.

Proses produksi dalam pembuatan krupuk ini adalah dari bahan baku dimasak dengan bumbu-bumbu khusus kemudian digiling sehingga menjadi lembaran-lembaran panjang dan kemudian dicetak sesuai dengan pesanan (bulat/kotak). Bahan baku yang digunakan oleh beliau adalah, tepung tapioka, tepung terigu, dan bumbu rempah-rempah. Adapun alat yang digunakan untuk membuat Krupuk beras sebagai berikut :

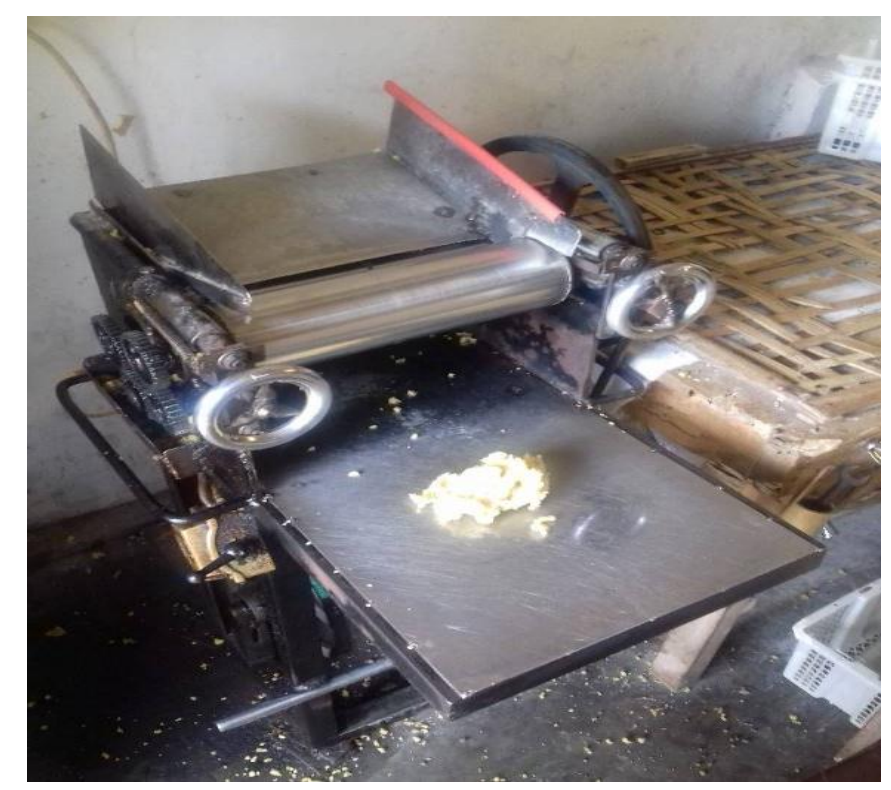

\section{Proses penggilingan Kerupuk}

1. Mesin Giling

Penggilingan adalah proses melumatkan atau memipihkan, tetapi juga dapat berarti memadatkan sejumlah butiran.

Mesin Penggiling mempunyai fungsi dalam memperkecil bidang padatan agar sesuai dengan peruntukan dalam proses berikutnya. Konstruksinya digerakkan oleh kekuatan roda penggiling yang berputar pada kecepatan yang diperlukan dan alas/tempat tidur beserta perlengkapan untuk memandu dan memegang kerja piece.

Jadi mesin giling krupuk beras berfungsi untuk menggiling bahan adonan menjadi halus dan tipis. Setelah penggilingan selesai maka alat penggiling krupuk beras tersebut harus segera dibersihkan dari segala jenis kotoran yang melekat. Pembersihan ini bermanfaat untuk mempertahankan atau memperpanjang umur pakai alat yang bersangkutan. 


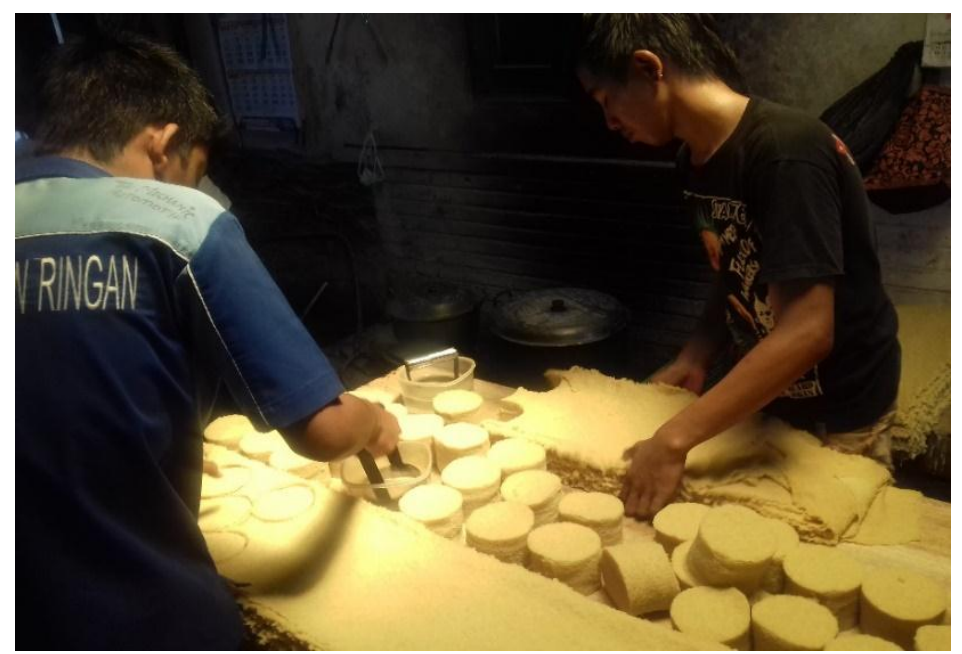

Proses Pencetak Kerupuk

2. Mesin Pencetak Krupuk

Mesin pencetak krupuk merupakan salah satu instrumen yang dibutuhkan dalam industri ini mengingat bentuk dan ketebalan krupuk menjadi poin penting dari krupuk itu sendiri sebenarnya proses pencetakan krupuk ini dilakukan secara tradisional yaitu dengan menggunakan alat-alat sederhana. Ada banyak bentuk krupuk yang beredar di pasaran, dimana dua bentuk yang paling umum adalah krupuk yang berbentuk bulat kecil dan krupuk berbentuk bulat besar bentuk krupuk ini dapat dihasilkan dengan penggunaan pencetak krupuk yang tepat.

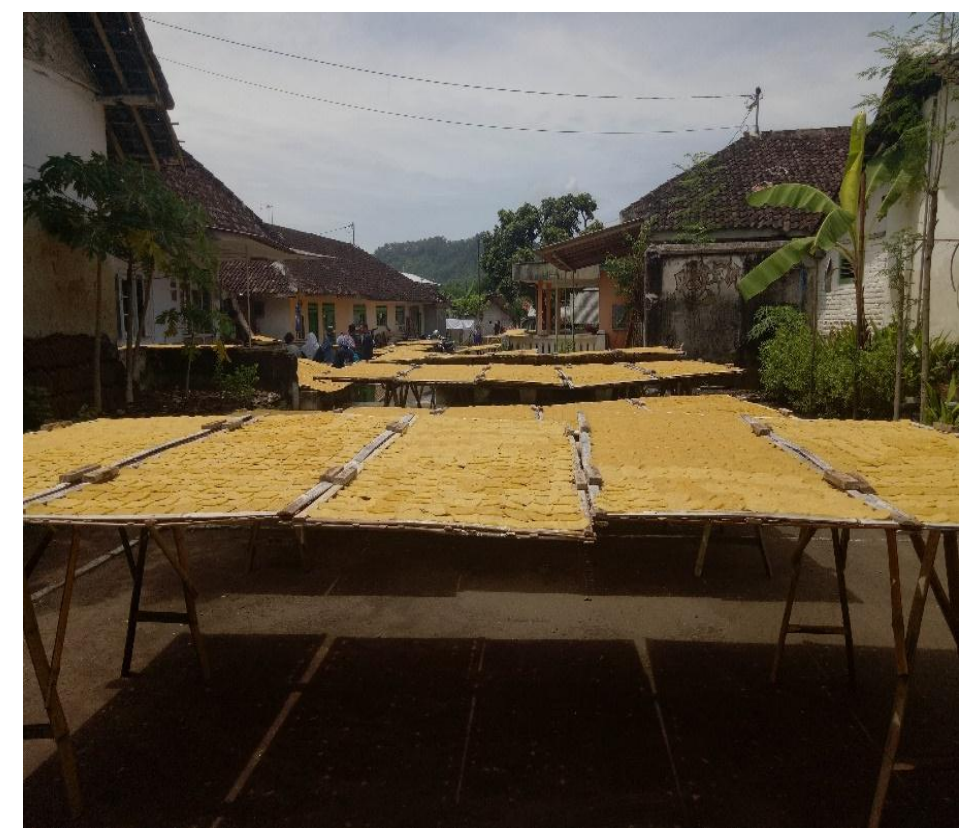

Proses Penjemuran Kerupuk 


\section{Proses Penjemuran Krupuk}

Penjemuran ini akan membuat awet krupuk beras selain itu tanpa dijemur krupuk tidak akan mengembang dengan sempurna saat digoreng penjemuran krupuk biasanya berlangsung selama satu hari sehingga krupuk benar-benar kering dan siap digoreng, krupuk yang telah benar-benar kering ditandai dengan warna krupuk yang berubah menjadi kecoklatan.

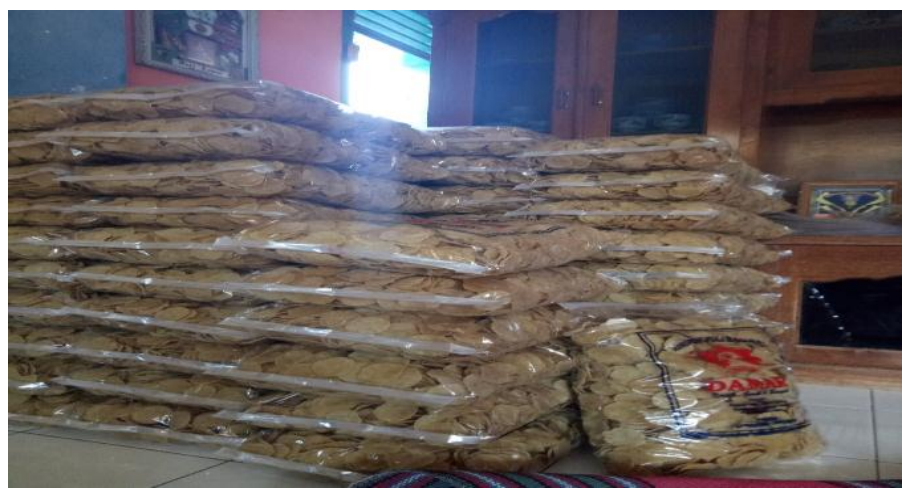

\section{Proses Pengemasan Kerupuk Beras}

4. Proses Pengemasan Krupuk

Pada saat menjalankan kegiatan usaha krupuk beras ini akan melalui proses penjemuran krupuk beras yang sudah selesai dibuat. Dalam melakukan proses penjemuran krupuk beras ini dilakukan dengan cara alami yaitu dengan memanfaatkan cahaya langsung dari matahari.

Pemilik usaha ini memiliki takaran khusus untuk menghitung jumlah satuan krupuk. Dalam setiap takaran timbangan ada 2,5kg krupuk. Untuk krupuk berukuran kecil mereka menjual sekitar harga 35.000, sedangkan krupuk berukuran besar mereka menjual sekitar harga 30.000 .

\section{Promosi Penjualan}

Strategi bauran pemasaran (Marketing mix), yakni Product, Price, Place, dan Promotion (4-P), satu sama lain saling berkaitan. Untuk setiap strategi yang akan ditetapkan harus mempertimbangkan strategi yang lain.

Secara umum definisi penjualan dapat diartikan sebagai usaha atau langkah konkrit yang dilakukan untuk memindahkan suatu produk, baik itu berupa barang ataupun jasa, dari produsen kepada konsumen sebagai sasarannya. Tujuan utama penjualan yaitu mendatangkan keuntungan atau laba dari produk atau barang yang dihasilkan produsennya dengan pengolahan yang baik. Dalam pelaksanaannya, penjualan sendiri tak akan dapat dilakukan tanpa adanya pelaku yang bekerja didalamnya seperti agen, pedagang dan tenaga pemasaran. 
Langkah-langkah dalam proses penjualan:

1. Memilih Prospek dan Menilai.

Langkah pertama dalam proses penjualan adalah memilih prospek (propecting), yaitu mencari siapa yang masuk sebagai pelanggan potensial. Tenaga penjual perlu mengetahui cara menilai prospek (qualify) artinya cara mengenali calon yang baik dan menisihkan calon yang jelek. Prospek dapat dinilai dengan meneliti kemampuan keuangan, volume bisnis, kebutuhan spesial, lokasi dan kemungkinan untuk tumbuh.

\section{Pra-pendekatan}

Sebelum menguji seorang calon pembeli, tenaga penjual sebaiknya mempelajari sebanyak mungkin mengenai organisasi (apa yang dibutuhkan, siapa yang terlibat dalam pembelian) dan pembelinya (karakteristik dan gaya membeli).

\section{Presentasi dan Demostrasi}

Tenaga penjual menceritakan produk kepada pembeli, menunjukan bagaimana produk akan menghasilkan dan menghemat uang.

Dalam menjalankan produksinya, pelaku usaha melakukan penjualan secara offline, atau dijual langsung di pasaran dan krupuk ini juga di jual di luar kota seperti Kediri, Blitar, Madiun, dan Tulungagung. Krupuk ini dijual perkemasan, satu kemasan sekitar 2,5 kg. Harga krupuk ini per kemasan seharga 30.000 jika di jual di sekitar Area. Sedangkan, di Luar kota harga sesuai jarak yang ditempuh.

\section{PENUTUP}

\section{A. Kesimpulan}

Program pengabdian masyarakat berjalan dengan baik dan lancar, pendampingan pemasaran yang telah diusulkan berhasil membuat penjualan meningkat. Kegiatan ini mendapat dukungan penuh dari kelompok usaha kerupuk beras di desa Jombang kecamatan Jombang kabupaten Jember.

\section{B. Saran}

Berdasarkan kegiatan yang telah dilakukan maka dapat diajukan beberapa saran sebagai berikut : 
1. Adanya kegiatan sejenis hendaknya selalu diselenggarakan secara periodik sehinga dapat meningkatkan penjualan.

2. Minimnya biaya operasional kegiatan menjadikan inovasi terbatas.

Selain peningkatan penjualan masih banyak kegiatan pengabdian masyarakat lain yang perlu dikembangkan seperti pelatihan managemen, pelatihan pencatatan akuntansi yang baik dan benar, dan sebagainya.

\section{DAFTAR PUSTAKA}

Prajaksa, Tegar. 2016. Kitab Pesugihan: 17 Rahasia Bisnis Dijamin Laris. Yogyakarta: Pustaka Ilmu 